(c) American Dairy Science Association, 2004.

\title{
Bacterial Populations on Teat Ends of Dairy Cows Housed in Free Stalls and Bedded with Either Sand or Sawdust
}

\author{
M. Zdanowicz, J. A. Shelford, C. B. Tucker, D. M. Weary, \\ and M. A. G. von Keyserlingk \\ Animal Welfare Program, Faculty of Agricultural Sciences, \\ 2357 Main Mall, University of British Columbia, \\ Vancouver, British Columbia, Canada V6T 1 Z4
}

\begin{abstract}
The main objectives of the experiment were: 1) to compare bacterial populations of mastitis-causing organisms on the teats of lactating dairy cattle housed on sand and sawdust bedding and, 2) to examine the relationship between bacterial counts present in the 2 bedding types with those on teat ends. Sixteen lactating Holstein cows were housed on either sand or sawdustbedded free stalls using a crossover design with $3 \mathrm{wk}$ per bedding type. Bedding samples were collected on d 0 (prior to animals lying on the bedding), 1, 2, and 6 . Teat ends were sampled prior to the morning milking on d 1,2 , and 6 . All samples were analyzed to determine coliform, Klebsiella spp., and Streptococcus spp. populations. There were 2 times more coliforms and 6 times more Klebsiella bacteria on teat ends of cows housed on sawdust compared with those housed on sand. In contrast, there were 10 times more Streptococcus spp. bacteria on teat ends of cows when housed on sand compared with sawdust. In both sawdust and sand bedding, coliforms, Klebsiella and Streptococcus counts increased over each experimental week, although patterns varied with bedding and bacteria type. Bacterial counts on teat ends were correlated with bacterial counts in sawdust ( $\mathrm{r}=0.47,0.69$, and 0.60 for coliforms, Klebsiella spp., and streptococci, respectively) and in sand $(r=0.35$ for coliforms and $r=0.40$ for Klebsiella spp.). In conclusion, coliforms and Klebsiella spp. on teat ends were more numerous when cows were housed on sawdust bedding, but Streptococcus spp. were more numerous on teat ends of cows housed on sand.
\end{abstract}

(Key words: bacterial count, sawdust, sand, teat end)

Abbreviation key: $\mathbf{M C}=$ MacConkey, $\mathbf{M C I C}=$ MacConkey-inositiol-carbenicillin.

\section{INTRODUCTION}

Cases of clinical mastitis result in substantial economic losses to dairy producers as well as impair the

Received August 6, 2003.

Accepted September 22, 2003.

Corresponding author: D. M. Weary; e-mail: danweary@ interchange.ubc.ca. health and welfare of affected cows (Andrews, 2000). Mastitis is one of the major causes of involuntary culling of lactating dairy cattle (Smith et al., 1985). Dairy producers are able to minimize the number of clinical mastitis cases caused by contagious pathogens through the implementation of dry cow therapy programs and use of germicidal teat dips (Smith et al., 1985). However, the incidence of environmental mastitis has proven to be much more difficult to control because sources of environmental pathogens include soil, feces, and bedding, all of which are found within dairy cattle housing systems. No single control treatment has been shown to be effective in eliminating IMI from environmental sources (Smith et al., 1985). Thus, it has been proposed that by minimizing the exposure of teat ends to pathogenic microorganisms and by maximizing the cows' resistance to infection, producers will be able to decrease the rates of environmental IMI in dairy herds (Smith et al., 1985).

Dairy cattle can spend between 40 and $65 \%$ of their time lying down (e.g., Manninen et al., 2002; Tucker et al., 2003), and bacteria can be transferred between the lying surface and the teats (Hogan and Smith, 1997; Hogan et al., 1999). Thus, in an effort to minimize teat end exposure to pathogenic microorganisms, it is important to understand the extent to which the lying surface contributes to the proliferation of bacteria. Previous work in this area focused on the differences in bacterial counts between inorganic and organic bedding (Fairchild et al., 1982; Janzen et al., 1982). Counts of bacteria in inorganic bedding are usually lower than those in organic bedding, depending on the bacterial strain and the type of material (Fairchild et al., 1982). Availability of nutrients, amount of moisture available, $\mathrm{pH}$, and stall cleanliness are the main factors thought to affect bacterial growth in bedding (National Mastitis Council, 1996). Sand bedding is becoming increasingly popular on North American dairy farms, in part, because farmers perceive an improvement in udder health and cow comfort (Bewley et al., 2001). However, there has been little work to date examining the bacterial 
strains prevalent in sand bedding (e.g., Fairchild et al., 1982; Hogan et al., 1989).

This experiment was designed to compare bacterial populations of mastitis-causing organisms on teats of cows housed on sand and on sawdust bedding. In addition, this experiment examined the relationship between the numbers of bacteria in bedding and on teat ends. Moreover, stall and udder cleanliness were assessed and compared for cows housed on sand and sawdust bedding. The associations between bacterial counts in bedding and the DM of the bedding and stall cleanliness were also explored.

\section{MATERIALS AND METHODS}

The experiment was conducted at The University of British Columbia Dairy Education and Research Center in Agassiz, BC, from April 18 to June 25, 2001. The animals were cared for according to standards set by the Canadian Council on Animal Care (1993) and approved by The University of British Columbia Animal Care and Use Committee.

\section{Experimental Design}

The experiment was a crossover design with 2 groups of Holstein cows. Each group rotated between 2 treatments: sand bedding and sawdust bedding. Groups were subjected to each treatment for $5 \mathrm{wk}$, but data were collected only during the last 3 wk of each period.

\section{Animals}

Sixteen lactating primaparous and multiparous Holstein cows were selected using the following criteria: 1) animals had previously been housed in stalls with sand and sawdust bedding (although the amount of previous experience with each bedding type was not measured); 2) they had no history of mastitis, and SCC were below 200,000 cells $/ \mathrm{mL}$ on their last 6 DHI reports; and 3) were less than 60 DIM. All animals were scored prior to treatment allocation for the presence of teat damage following Britt and Farnsworth (1996). Animals were then assigned into 2 experimental groups (8 animals per group) balanced according to parity (average = 2.25 ), stage of lactation (average $=40 \mathrm{DIM}$ ), and teat end score (average $=1.3$ ).

\section{Udder Cleanliness}

The amount of fecal matter on the rear udder of all experimental cows was recorded on $\mathrm{d} 1,2$, and 6 (at the time of teat sampling before udder cleaning in preparation for milking). A $100-\mathrm{cm}^{2}$ metal grid, containing
16 equal-sized squares, was placed on the rear side of the udder immediately above the teats to the top of the udder, and the total number of squares containing any visible fecal matter was recorded.

\section{Housing}

Cows were housed in 2 different pens within a freestall barn. Each pen had 2 rows of 4 deep-bedded stalls each ( 8 stalls per pen), facing one another ('head-tohead'). Each stall was $240 \mathrm{~cm}$ long and $117.5 \mathrm{~cm}$ wide, and the bedding was approximately $40 \mathrm{~cm}$ deep. Sand bedding was stored outside and consisted of river sand purchased from Armstrong Sand and Gravel Ltd. (Rosedale, BC), which had been previously sieved over a 2-mm screen with water to wash out any silt. Kilndried softwood sawdust was obtained from Friesen Bros. Inc. (Burnaby, BC) and stored in a shed until needed. Visible fecal matter and urine were removed twice daily, and fresh bedding added every $7 \mathrm{~d}$. Animals were fed a 50:50 forage to concentrate TMR and milked twice a day at 0600 and $1600 \mathrm{~h}$.

\section{Stall Cleanliness}

The amount of fecal matter in each stall was recorded $3 \mathrm{~d}$ per week (at the time of bedding sampling but before daily removal of any visible fecal material) to assess stall cleanliness. A $1-\mathrm{m}^{2}$ metal grid, containing 100 equal-sized squares, was placed along the back of the stall and centered between the stall partitions, and the total number of squares containing any visible fecal matter was recorded.

\section{Behavioral Observations}

Each pen was videotaped using a single camera (Panasonic WV-BP330) attached to a video multiplexer (Panasonic WJ-FS 216) and a time-lapse videocassette recorder (Panasonic AG-6540). Pens were recorded for $12 \mathrm{~h}$ before sampling on $\mathrm{d} 1,2$, and 6 of each experimental week. To enable recording during the dark period, a red light $(100 \mathrm{~W},<5 \mathrm{~lx})$ was suspended over each pen. All animals were uniquely identified with a symbol marked with hair dye (black or blonde) on their backs. Videotapes were scored using scan sampling at 10-min intervals. At each scan, we recorded which cows were lying down in each stall. This sampling regime allowed us to estimate the amount of time each cow spent lying in each stall between the evening and morning milking, and thus determine the potential exposure to microorganisms found in the bedding. 


\section{Bedding Samples}

Bedding samples were taken on d 0 (immediately after fresh bedding was added to stalls), 1, 2, and 6 of every week, during the morning milking. A 118-mL sterile plastic scoop (Bel-Art Products) was used to collect bedding samples from 16 randomly selected locations within the previously described metal grid in the back $1 \mathrm{~m}^{2}$ of each stall. Bedding samples were collected from the same locations within the grid at each sampling. The edge of the plastic scoop was placed below the bedding surface and pulled upward, collecting all material from $10 \mathrm{~cm}$ to the surface. Bedding samples collected in this manner were thought to be representative of the material dairy cattle are likely to contact while lying, as animals often reposition bedding when performing this behavior. Total amount of material (approximately $0.5 \mathrm{~kg}$ ) collected was consistent throughout the experiment. Samples from a single stall were combined in sterile 710-mL Whirl-Pak plastic bags (Nasco, Inc.). These composite samples were immediately taken to the laboratory, where they were analyzed for bacterial counts.

Wet bedding samples were thoroughly mixed by swinging the plastic bag from side to side in $90^{\circ}$ arc for 5 min. Sample DM was determined by placing a $25-\mathrm{g}$ composite sample in a convection oven at $100^{\circ} \mathrm{C}$ for 24 $\mathrm{h}$ or until constant weight was achieved. Samples for microbiological analyses were prepared by adding $10 \mathrm{~g}$ of the mixed wet bedding sample plus $90 \mathrm{~mL}$ of sterile $0.1 \%$ peptone solution to a $118-\mathrm{mL}$ Qorpak square glass bottle (All-Pak, Inc.). Bottles were then mixed thoroughly by swinging the bottles from side to side in $30^{\circ}$ arc for $5 \mathrm{~min}$. Bottle contents were allowed to settle for 2 to $3 \mathrm{~min}$ and appropriate dilutions $\left(10^{2}, 10^{3}, 10^{4}, 10^{5}\right.$, $\left.10^{6}, 10^{7}\right)$ of the liquid phase were plated for enumeration on the surface of MacConkey agar (MC) (Beckman Dickinson Microbiology Systems, Canada), MacConkey-inositiol-carbenicillin agar (MCIC) (Beckman Dickinson Microbiology Systems), and Streptosel agar (Beckman Dickinson Microbiology Systems). Prior to plating, each Petri dish was divided into 2 equal parts by drawing a line on the plastic lid of the dish using a black felt marker. This was done so that each Petri dish could be used for plating 2 dilutions. Inositol (10 mg/L BBB) and carbenicillin (BBB) were added to MC agar for MCIC as described by Bagley and Sheidler (1978). Inoculum $(0.1 \mathrm{~mL})$ was spread on the agar plates with a sterilized steel spreader. Inoculated agar plates were incubated for $24 \mathrm{~h}$ at $37^{\circ} \mathrm{C}$, and bacteria were counted using standard enumeration methods (Tortora et al., 1998). Only plates containing 20 to 200 colonies were used to estimate bacterial counts, and all plates showing visible signs of cross contamination were discarded. Bacterial counts were expressed as $\log _{10}$ cfu per gram of sample. Bacterial groups were identified as coliforms (lactosepositive colonies on MC agar), Klebsiella spp. (pink to red colonies on MCIC), and streptococci (total growth on Streptosel agar).

\section{Teat Samples}

Teat samples were taken on d 1,2, and 6 of each experimental week and were collected before the morning milking using a BBL Collection and Transport Culture Swab (BD Microbiology Systems, Canada). Teat swabs were collected individually from all 4 teats by rotating a swab around the exterior of the teat orifice. Teat swabs were analyzed immediately for coliforms, Klebsiella spp., and Streptococcus spp. counts. The 4 swabs from each cow were pooled by placing them in a single test tube containing $4 \mathrm{~mL}$ of peptone solution and shaken vigorously in a circular motion for $60 \mathrm{~s}$. Rinse solution and its dilutions $\left(10^{2}, 10^{3}, 10^{4}\right)$ were plated on the 3 types of agar media and processed as described previously for the bedding samples.

\section{Statistical Analyses}

All dependent variables were screened for normality, and the presence of outliers by visual assessment of the distributions and by calculation of kurtosis and skewness (Proc Univariate in SAS, version 8.2). Bacterial counts were normalized by logarithmic transformations.

Our experiment was not designed to allow for a statistical test of treatment differences for the bacterial counts in the stall bedding. However, differences in this measure could be compared among days within treatment. The experiment was designed to allow for treatment comparisons of cow-based measures (udder cleanliness score and bacterial counts on teat ends). These variables were averaged across the $3 \mathrm{wk}$ on each treatment to calculate one value per cow, per treatment, and per experimental day. Mixed model analysis was then used to test the effect of treatment (Proc Mixed, SAS, version 8.2). In the model, day, treatment (type of bedding), and day $\times$ treatment interaction were included as fixed effects, and cow was treated as the random effect. The ARH (1) (heterogeneous first-order autoregressive) covariance structure was used to test differences for udder cleanliness between treatments. For the bacterial counts, the ANTE (1) (first-order Antedependence) covariance structure provided the best fit for all 3 types of bacteria. This analysis revealed significant interactions between day and treatment for all 3 bacterial types; therefore, paired t-tests were used to test the differences between treatments on each day. 
A) Coliforms - sand

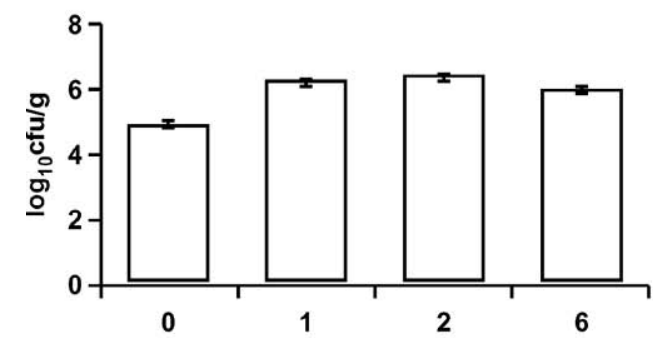

C) Klebsiella spp. - sand

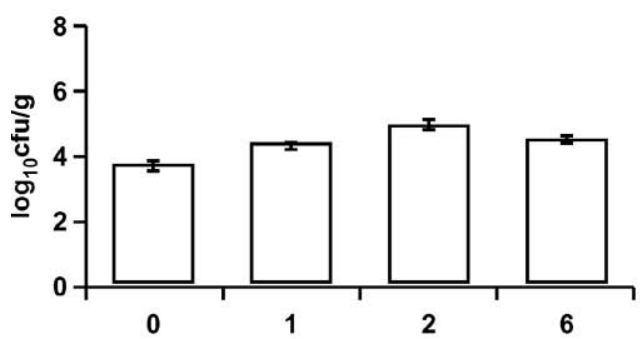

E) Streptococcus spp. - sand

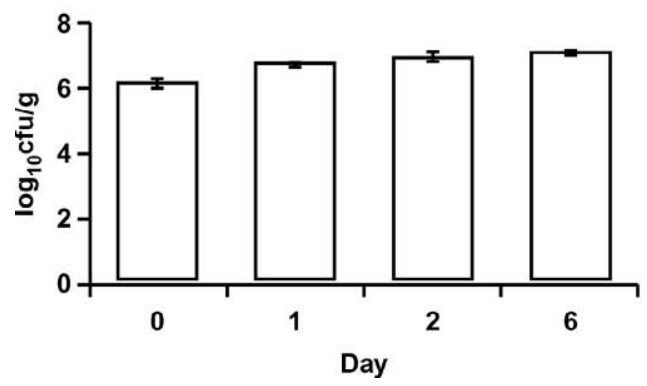

B) Coliforms - sawdust

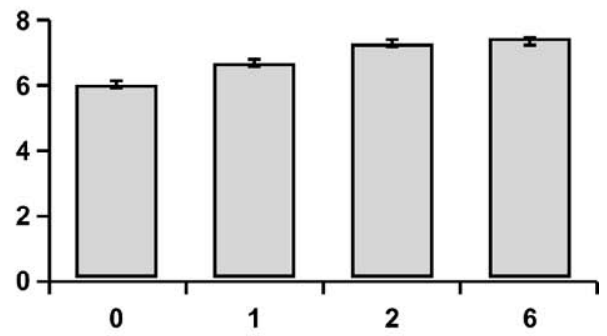

D) Klebsiella spp. - sawdust

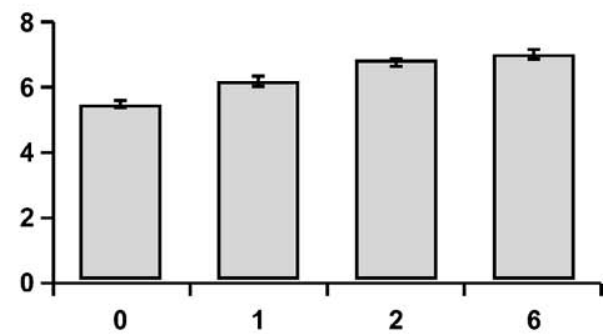

F) Streptococcus spp. - sawdust

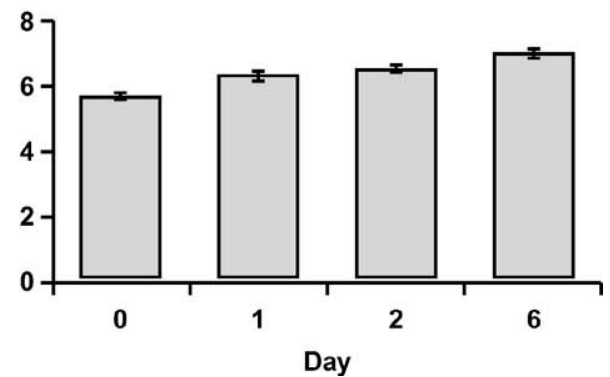

Figure 1. Mean + standard error counts of coliforms in sand (A) and sawdust (B), Klebsiella spp. in sand (C) and sawdust (D), and streptococci in sand (E) and sawdust (F) on d 0,1,2, and 6 after the addition of fresh bedding in 16 free stalls.

Pearson correlation coefficients were used to estimate the associations among bacterial counts in bedding, bacterial counts on teat ends, DM, udder, and stall cleanliness, based on the average values over all experimental weeks.

Correlations between bedding counts and teat counts were determined with the aid of behavioral observations. We calculated the amount of time each cow spent lying in each stall between the previous evening milking and morning milking (usually about $10 \mathrm{~h}$ ) on $\mathrm{d} 1$, 2 , and 6 . The number of hours each animal spent lying in a given stall was then multiplied by the bacterial count for that particular stall. In cases in which cows used multiple stalls, this procedure was repeated for each stall and then summed for all stalls. This summed value resulted in a 'cow-bedding count' for each individual cow. The 'cow- bedding count' was then correlated with the bacterial count found on the teat ends of each individual animal. Correlations between bedding counts and teat counts were calculated for all $6 \mathrm{wk}$ of the experimental period.

\section{RESULTS}

\section{Bedding Samples}

Coliforms. Coliform counts in sand bedding were approximately $1.1 \log$ units lower on $d 0$ than on $d 1$, 
Table 1. Means and least-square SE for bedding DM (\%) and stall cleanliness (grid count) for 16 free stalls observed over 6 wk with either sand or sawdust bedding.

\begin{tabular}{llllll}
\hline & \multicolumn{5}{c}{ Day } \\
\cline { 2 - 5 } Bedding type & 0 & 1 & 2 & 6 & LS SE \\
\hline \% DM & & & & & \\
Sand & 93.7 & 95.1 & 95.3 & 94.9 & 0.8 \\
$\quad$ Sawdust & $86.9^{\mathrm{a}}$ & $80.5^{\mathrm{b}}$ & $79.1^{\mathrm{b}}$ & $71.7^{\mathrm{c}}$ & 0.8 \\
Stall cleanliness & & & & & \\
$\quad$ Sand & - & $5^{\mathrm{a}}$ & $7^{\mathrm{a}}$ & $11^{\mathrm{b}}$ & 1 \\
Sawdust & - & $12^{\mathrm{a}}$ & $14^{\mathrm{ab}}$ & $16^{\mathrm{b}}$ & 1 \\
\hline
\end{tabular}

${ }^{\mathrm{a}, \mathrm{b}}$ Means with different superscripts differ within the row $(P<0.01)$.

2 , or $6(P<0.001$; Figure $1 \mathrm{~A})$, but varied little over the rest of the week. In sawdust, coliform numbers peaked by d 2 (Figure $1 \mathrm{~B}$ ). Coliform counts in sawdust were lower on $\mathrm{d} 0$ and 1 than on $\mathrm{d} 2$ and $6(P<0.001)$, with $1.2 \mathrm{log}$ units fewer coliforms on $\mathrm{d} 0$ than on $\mathrm{d} 2$. Of particular interest, the highest coliform count for sand (on d 2) was similar to the lowest count observed for sawdust (on d 0).

Klebsiella. In sand, there were approximately 1.1 log units more Klebsiella spp. on d 2, and 6 than on d $0(P<0.001$; Figure 1C). Counts were similar on d 0 and 1 , and on d 2 and 6 . In sawdust, Klebsiella spp. counts were lowest on $\mathrm{d} 0$, and slowly increased reaching maximum levels by d $2(P<0.01 ;$ Figure 1D). There were $1.3 \log$ units more Klebsiella spp. on d 2 than on d 0. The highest Klebsiella spp. counts in sand (on d 2 ) were numerically lower than the lowest counts in sawdust (on d 0).

Streptococci. In sand, there were more streptococci on $\mathrm{d} 1,2$, and 6 than on $\mathrm{d} 0(P<0.001$; Figure $1 \mathrm{E})$. Counts increased by $0.6 \mathrm{log}$ units from $\mathrm{d} 0$ to 2 and then leveled out between $d 2$ and 6 . In sawdust bedding, streptococcal counts increased continually from $\mathrm{d} 0$ to $6(P<0.01$; Figure $1 \mathrm{~F})$.

\section{Dry Matter}

The mean values for DM over the experiment were 94.7 and $79.5 \%$ for sand and sawdust bedding, respectively (Table 1). Dry matter content of sand bedding did not differ between sampling days. However, the DM in sawdust bedding decreased significantly throughout the week $(P<0.001)$ with the lowest DM $(71.7 \%)$ occurring on $\mathrm{d} 6(P<0.001)$.

\section{Stall and Udder Cleanliness}

For both types of bedding, the stalls became increasingly contaminated with feces over the course of the week (Table 1). The mean grid count for sand and sawdust bedding was 7 and 14 , respectively.
Table 2. Means and least square SE for udder cleanliness (grid count) over 6 wk of observations for 16 cows housed on sand and sawdust bedding.

\begin{tabular}{llll}
\hline & \multicolumn{2}{c}{ Bedding type } & \\
\cline { 2 - 3 } Day & Sand & Sawdust & LS SE \\
\hline 1 & $6^{\mathrm{a}}$ & $3^{\mathrm{b}}$ & 0.5 \\
2 & $6^{\mathrm{a}}$ & $4^{\mathrm{b}}$ & 0.5 \\
6 & $7^{\mathrm{a}}$ & $5^{\mathrm{b}}$ & 0.5 \\
\hline \multicolumn{2}{c}{ a,b Means with different superscripts differ within the row $(P<0.01)}$.
\end{tabular}

Udders of cows housed on sand had a higher grid count score than cows housed on sawdust (6 and 4, respectively; $P<0.001)$. However, udder cleanliness for cows housed on sand and sawdust did not change over the course of the week (Table 2).

\section{Teat End Swabs}

Coliforms. Coliform counts on teat ends of cows housed on sand were higher on d 2 than on $d 1$ and 6 $(P<0.001, P<0.05$; Figure 2A). In contrast, the coliform counts of cows housed on sawdust increased during the week, with the lowest count occurring on $\mathrm{d} 1$ and the highest count on d 6 ( $P<0.01$; Figure $2 \mathrm{~A})$. Coliform counts on teat swabs were the same for the 2 bedding treatment groups on $\mathrm{d} 1$ and 2 . However, by d 6, cows bedded on sand had 1 log unit fewer bacteria than cows bedded on sawdust $(P<0.001)$.

Klebsiella. For cows housed on sand, there were more Klebsiella spp. on teat ends on d 2 than on d 1 $(P=0.001)$, but little difference between $\mathrm{d} 1$ and 6 , or d 2 and 6 (Figure 2B). However, Klebsiella spp. counts from teat swabs taken from cows housed on sand on $d$ 1 were often below the sensitivity of the plating procedures $\left(<10^{-2} \mathrm{cfu} / \mathrm{g}\right)$. Klebsiella spp. counts on teat ends of cows housed on sawdust increased steadily during the week $(P<0.001)$. Overall, there were $0.8 \log$ units more Klebsiella spp. on the teat swabs collected from cows when bedded on sawdust compared with when they were housed on sand $(P<0.001)$. The highest count for cows bedded on sand was similar to the lowest count for cows bedded on sawdust.

Streptococci. Streptococcal counts on teat swabs for cows bedded on sand were similar on $\mathrm{d} 1$ and 2 , but greater on d $6(P<0.01)$ (Figure $2 \mathrm{C})$. However, when cows were bedded on sawdust, teat swab counts increased progressively during the course of the week with highest counts occurring on d $6(P<0.001)$. Cows bedded on sand had on average 1 log unit higher streptococcal counts than those bedded on sawdust $(P<$ 0.001). The lowest count for the cows bedded on sand was similar to the highest count for cows bedded on sawdust. 

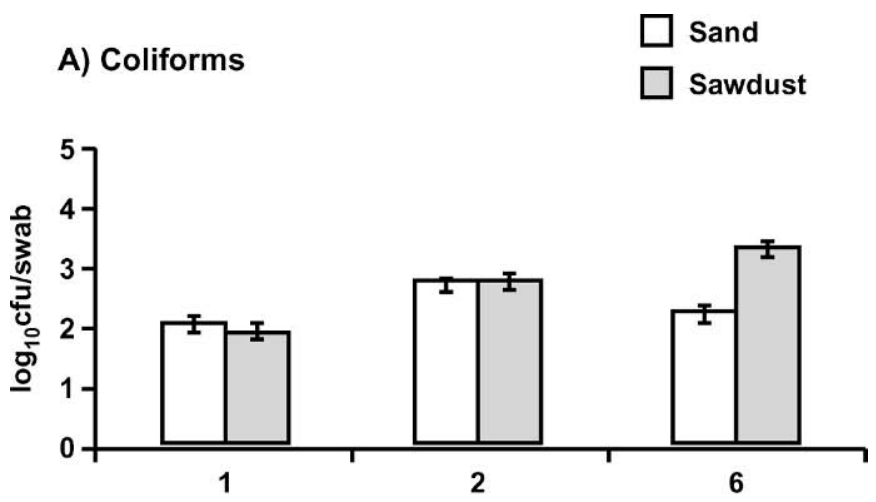

B) Klebsiella spp.

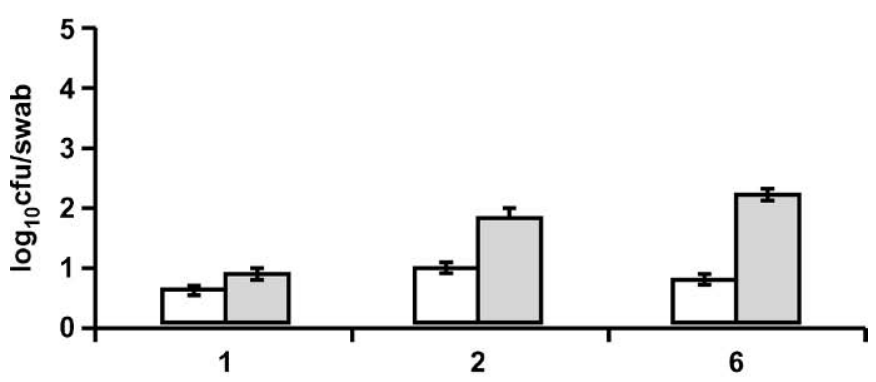

C) Streptococcus spp.

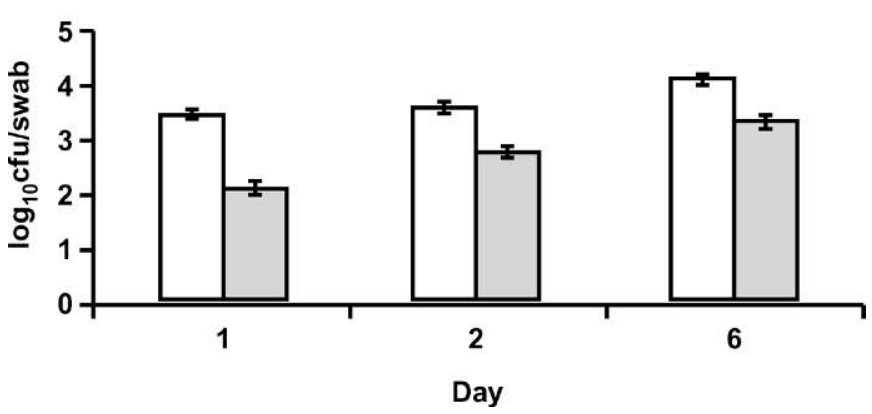

Figure 2. Mean + standard error counts of coliforms (A), Klebsiella spp. (B), and Streptococcus spp. (C) from teat swabs of 16 cows bedded on sand and sawdust on d 1, 2, and 6 after the addition of fresh bedding to the free stalls.

\section{Correlations Between Bacterial Counts in Bedding and on Teat Ends}

For sand bedding, cow-bedding count was correlated with bacterial counts on teat swabs for coliforms $(\mathrm{r}=$ $0.35 ; P<0.05)$ and Klebsiella spp. $(\mathrm{r}=0.40 ; P<0.05)$, but only marginally for streptococci $(\mathrm{r}=0.28 ; P=0.06)$. For cows on the sawdust treatment, correlation coefficients were $\mathrm{r}=0.47,0.69$, and $0.60, P<0.001$, for coliforms, Klebsiella spp., and streptococci, respectively.

\section{Correlations Between Udder Cleanliness and Bacterial Counts on Teat Ends}

The cleanliness of the udder and the bacterial counts on teat ends were correlated, but the strength and direction of the correlation varied with day, bacteria type, and bedding (Table 3). Overall, there was no clear relationship between these measures.

\section{Correlations Between Bacterial Counts and DM of Bedding}

For sawdust bedding samples, counts of all 3 types of bacteria were higher in samples with lower DM ( $\mathrm{r}=$ $-0.57,-0.47$, and $-0.66 ; P<0.001$, for coliforms, Klebsiella spp., and streptococci). For sand bedding, the only significant relationship was a positive correlation between coliform counts and bedding DM $(\mathrm{r}=0.31 ; P$ $<0.01$ ).

\section{Correlation Between Bedding Counts and Stall Cleanliness}

Dirtier stalls, as measured by our stall cleanliness score, contained more of all 3 types of bacteria. Correlation coefficients between bacterial counts in sand and stall cleanliness were $\mathrm{r}=0.46(P<0.001)$ for coliforms, $\mathrm{r}=0.50(P<0.001)$ for Klebsiella spp., and $\mathrm{r}=0.48$ $(P<0.001)$ for streptococci. Correlation coefficients for bacterial counts in sawdust were $\mathrm{r}=0.43(P<0.001)$ for coliforms, $\mathrm{r}=0.30(P<0.001)$ for Klebsiella spp., and $\mathrm{r}=0.35(P<0.001)$ for streptococci.

Table 3. Pearson correlation coefficients between bacterial counts on teat ends and udder cleanliness measured over 6 wk of observations for 16 cows housed on sand and sawdust bedding.

\begin{tabular}{|c|c|c|c|c|c|c|c|c|c|c|}
\hline \multirow[b]{3}{*}{ Bacteria type } & \multicolumn{6}{|c|}{ Day } & \multicolumn{4}{|c|}{ Bedding type } \\
\hline & \multicolumn{2}{|c|}{1} & \multicolumn{2}{|c|}{2} & \multicolumn{2}{|c|}{6} & \multicolumn{2}{|c|}{ Sand } & \multicolumn{2}{|c|}{ Sawdust } \\
\hline & $\mathrm{r}$ & $\mathrm{p}$ & $\mathrm{r}$ & $\mathrm{p}$ & $\mathrm{r}$ & $\mathrm{p}$ & $\mathrm{r}$ & $\mathrm{p}$ & $\mathrm{r}$ & $\mathrm{p}$ \\
\hline Coliforms & 0.03 & 0.87 & -0.29 & 0.11 & -0.42 & 0.02 & -0.28 & 0.05 & 0.22 & 0.14 \\
\hline Klebsiella spp. & -0.23 & 0.21 & -0.34 & 0.06 & -0.49 & 0.004 & -0.20 & 0.16 & 0.15 & 0.31 \\
\hline Streptococcus spp. & 0.38 & 0.03 & -0.00 & 1.00 & 0.25 & 0.17 & -0.29 & 0.04 & 0.28 & 0.05 \\
\hline
\end{tabular}




\section{DISCUSSION}

Bacterial counts on the teat ends of the cows in this study were moderately correlated with bacterial counts in the sawdust bedding, and this relationship is consistent with previous reports in the literature (Rendos et al., 1975; Hogan et al., 1989; Hogan et al., 1999; Hogan and Smith, 1997). The r-values for this relationship when cows were using sawdust-bedded stalls were well within the range previously described in other experiments. For example, Hogan and Smith (1997) reported correlation coefficients for bacterial counts in sawdust and teat end swabs: $r=0.62$ for coliforms, $r=0.78$ for Klebsiella spp., and $\mathrm{r}=0.90$ for streptococci. However, their experiment used cows housed in tie stalls; whereas the present experiment provides the first evidence of this relationship for dairy cattle housed in free stalls. The use of free-stall housing equipped with video cameras allowed us to estimate the exposure to the bacterial populations present in the lying material by calculating the 'cow-bedding count,' and correlating this measure to bacterial counts on teat ends.

For sand bedding, the relationship between bacterial counts in bedding and on teat ends was relatively weak, suggesting that the way teat ends become contaminated is different in this medium. The physical properties of sand (e.g., adhesion to skin and abrasiveness) may influence bacterial exposure in a more sporadic manner than is the case for sawdust. Cows in this study had dirtier rear udders when housed on sand than on sawdust, but udder cleanliness was not consistently correlated to bacteria counts on the teat end. Some measure of teat cleanliness may have been a better predictor of teat end bacterial counts. Coliforms are complex organisms found in many bedding materials and can metabolize a variety of organic compounds (Madigan et al., 2000). Counts of both coliforms and Klebsiella spp. were higher on teat ends of cows housed on sawdust compared with sand. These findings are in agreement with other studies (Bramley and Neave, 1975; Fairchild et al., 1982; Janzen et al., 1982). In the current experiment, we found between 0.8 and $1 \log$ units more coliforms and Klebsiella spp. on the teat ends of cows when they were bedded with sawdust compared with sand. Similarly, Fairchild et al. (1982) and the National Mastitis Council (1996) found higher coliform and Klebsiella spp. counts in sawdust bedding than in sand.

Other work has found that Klebsiella outbreaks are often associated with sawdust bedding (Bramley and Neave, 1975; Fairchild et al., 1982). The degree of contamination by this pathogen can vary depending on the type of wood, the kiln-drying process and the handling and storage of sawdust on the farm (Zehner et al., 1986).
In the present experiment, sawdust was stored indoors to reduce the chance of environmental contamination.

Previous work has shown that feces and urine contamination of bedding plays an important role in bacterial multiplication (Carroll and Jasper, 1978; Zehner et al., 1986; National Mastitis Council, 1996). Over the course of a week, stalls bedded with sawdust were more likely to become contaminated with manure and have lower DM levels. In contrast, the DM content of the sand bedding remained constant over the week regardless of the extent of manure contamination. Greater numbers of coliform and Klebsiella colonies associated with sawdust can be attributed to the presence of moisture and availability of nutrients. Not surprisingly, coliforms, Klebsiella spp., and streptococci counts in sawdust were positively correlated with bedding DM, and bedding counts were positively correlated with stall cleanliness.

Actual bacterial counts varied during the course of the week for both sand and sawdust bedding. Bacterial counts in sawdust increased at the beginning of the week, reaching their maximum population numbers by $\mathrm{d} 2$. The initial bacterial populations may be due to the availability of nutrients in fresh sawdust. As the week progressed, the sawdust bedding became more contaminated with manure, possibly resulting in differences in nutrient availability for bacteria. However, competition between bacterial populations also likely increased over this period. Hogan and Smith (1997) and Hogan et al. (1999) reported similar time trends for bacterial growth within sawdust bedding. In the present experiment, teat ends of cows housed on sand had at least 1 log unit more streptococci compared with the teat ends of cows housed on sawdust bedding. These results are in contrast to those of Janzen et al. (1982), who reported lower bacterial counts.

\section{ACKNOWLEDGMENTS}

We thank the staff and students at the University of British Columbia's Dairy Education and Research Center. We especially thank Uri Burstyn and Tyler Vittie for their help in running this experiment. This project was supported by the South Coastal Dairy Education Association and Investment Agriculture. General support for our research program was by the Natural Sciences and Engineering Research Council through the Industrial Research Chair in Animal Welfare, and by contributions from the Dairy Farmers of Canada, the Beef Cattle Industry Development Fund, the BC Dairy Foundation, the BC SPCA, members of the BC Veterinary Medical Association and many others listed at www.agsci.ubc.ca/animalwelfare. 


\section{REFERENCES}

Andrews, A. H., ed. 2000. The Health of Dairy Cattle. Blackwell Science, Oxford, UK.

Bagley, S. T., and R. J. Sheidler. 1978. Primary Klebsiella identification with MacConkey-inositol-carbenicillin agar. Appl. Environ. Microbiol. 6:536-539.

Bewley, J., R. W. Palmer, and D. B. Jackson-Smith. 2001. A comparison of free-stall barns used by modernized Wisconsin dairies. J. Dairy Sci. 84:528-541.

Bramley, A. J., and F. K. Neave. 1975. Studies on the control of coliform mastitis in dairy cows. Br. Vet. J. 131:160-169.

Britt, J. S., and R. Farnsworth. 1996. Here's a system for evaluating teat condition. Hoard's Dairyman. August 25. page 570.

Canadian Council on Animal Care. 1993. Guide to the Care and Use of Experimental Animals. Volume 1. CCAC, Ottawa, Canada.

Carroll, E. J., and D. E. Jasper. 1978. Distribution of Enterobacteriaceae in recycled manure bedding on California dairies. J. Dairy Sci. 61:1498-1508.

Fairchild, T. P., B. J. McArthur, J. H. Moore, and W. E. Hylton. 1982. Coliform counts in various bedding material. J. Dairy Sci. 65:1029-1035.

Hogan, J. S., K. L. Smith, K. H. Hoblet, D. A. Todhunter, P. S. Shoenberger, W. D.Hueston, D. E. Pritchard, G. L. Bowman, L. E. Heider, B. L. Brockett, and H. R. Conrad. 1989. Bacterial counts in bedding materials used on nine commercial dairies. J. Dairy. Sci. 72:250-258.

Hogan, J. S., and K. L. Smith. 1997. Bacteria counts in sawdust bedding. J. Dairy Sci. 80:1600-1605.

Hogan, J. S., V. L. Bogacz, L. M. Thompson, S. Romig, P. S. Schoenberger, W. P. Weiss, and K. L. Smith. 1999. Bacterial counts associated with sawdust and recycled manure bedding treated with commercial conditioners. J. Dairy 82:1690-1695.

Janzen, J. J., J. R. Bishop, A. B. Bodine, C. A. Caldwell, and D. W. Johnson. 1982. Composted dairy waste solids and crushed limestone as a bedding in freestalls. J. Dairy Sci. 65:1025-1028.

Madigan, M. T., J. M. Martinko, and J. Parker. 2000. Brock Biology of Microorganisms. 9th ed. Prentice Hall, Upper Saddle River, NJ.

Manninen, E., A. M. dePassill, J. Rushen, M. Norring, and H. Saloniemi. 2002. Preferences of dairy cows kept in unheated buildings for different kind of flooring. Appl. Anim. Behav. Sci. 75:281-292.

National Mastitis Council. 1996. Current Concepts of Bovine Mastitis. National Mastitis Council, Madison, WI.

Rendos, J. J., R. J. Eberhart, and E. M. Kesler. 1975. Microbial populations of teat of dairy cows, and bedding materials. J. Dairy Sci. 58:1492-1500.

SAS User's Guide: Statistics, Version 8.2 Edition. 2002. SAS Inst., Inc., Cary, NJ.

Smith, K. L., D. A. Todhunter, and P. S. Schoenberger. 1985. Environmental mastitis: Causes, prevalence, prevention. J. Dairy Sci. 68:1531-1553.

Tortora, G. J., B. R. Funke, and C. L. Case. 1998. Microbiology: an Introduction. Benjamin/Cummings Publishing Co. Inc., Menlo Park, CA.

Tucker, C. B., D. M. Weary, and D. Fraser. 2003. Effects of three types of freestall surfaces on preferences and stall usage by dairy cows. J. Dairy Sci. 86:521-529.

Zehner, M. M., R. J. Farnsworth, R. D. Appleman, K. Larntz, and J. A. Springer. 1986. Growth of environmental mastitis pathogens in various bedding materials. J. Dairy Sci. 69:1932-1941. 